\title{
VEREADORES CATÓLICOS: ELEMENTOS PARA A REFLEXÃO SOBRE A DIVERSIDADE ARTICULADA NO CAMPO POLÍTICO
}

\author{
Antônio J.F. de Lima, Bruno Ribeiro Marques, \\ Jonas de Souza Castilhos, Thais Vanessa Salvador
}

Resumo: Este texto busca expor e relacionar traços presentes nas narrativas de quatro vereadores da Câmara Municipal de Porto Alegre, integrantes do Grupo de Vereadores Católicos. Através de um exercício em que se salientam as semelhanças entre aspectos que pareceriam, a um primeiro olhar, heterogêneos, e as diferenças naquilo que pareceria homogêneo, refletimos sobre a possibilidade da diversidade de compreensões político-ideológicas e religiosas (revelada nas narrativas dos vereadores) articular-se em um mesmo grupo com referência no catolicismo. Interpretamos, assim, uma certa "particularidade" católica atualizandose no campo político.

Palavras-chave: diversidade, Igreja Católica, religião, política, vereadores.

Keywords: diversity, church's catholic, religion, politics, tow n councillor.

Em virtude da sua missão de iluminar o mundo inteiro com a mensagem de Cristo e de reunir em um só Espírito todos os homens, de qualquer nação, raça ou cultura, a igreja constitui um sinal daquela fraternidade que torna possível e fortalece o diálogo sincero. Isto exige, em primeiro lugar, que, reconhecendo toda a legítima diversidade, promovamos na própria igreja a

Agradecemos às contribuições de Daniel Alves, Nair Cauduro Negrão e ao acompanhamento e leitura atenciosa de Carlos Alberto Steil (professor do Departamento de Antropologia da UFRGS). Agradecemos também aos interlocutores que contribuíram na realização deste trabalho.

${ }^{1}$ Os autores são graduandos em Ciências Sociais na Universidade Federal do Rio Grande do Sul e participam como auxiliares de pesquisa em projetos ligados ao NER (Núcleo de Estudos da Religião). 
mútua estima, o respeito e a concórdia, em ordem a estabelecer entre todos os que formam o povo de Deus, Pastores ou fiéis, um diálogo cada vez mais fecundo. Porque o que une entre si os fiéis é bem mais forte do que aquilo que os divide: haja unidade no necessário, liberdade no que é duvidoso, e em tudo caridade. (Roma, junto de São Pedro, no dia 7 de dezembro de 1965 conclusão do Concilio Vaticano II)

A realização de um trabalho etnográfico sobre candidatos integrantes do Grupo de Vereadores Católicos, ${ }^{2}$ aspirantes à reeleição para a Câmara Municipal de Porto Alegre, no pleito de 2004, traz elementos para pensarmos a multiplicidade de formas em que as articulações entre religião e política podem se atualizar na contemporaneidade. O interesse inicial da pesquisa, e excessivamente amplo, pelo levantamento dos "candidatos católicos" para a vereança nas eleições 2004 em Porto Alegre, foi se deslocando em direção ao aprofundamento no caso de quatro candidatos integrantes do Grupo de Vereadores Católicos, bem como um breve estudo da atuação da Igreja Católica neste grupo através dos clérigos responsáveis pela sua fundação e coordenação. Portanto, é um estudo que, mesmo realizado com candidatos na época das eleições, não é focado exclusivamente no processo eleitoral. Na verdade, o que se busca são alguns traços narrativos presentes em campos de observação como a campanha eleitoral, trajetória pessoal, atuação como vereador e membro do Grupo de Vereadores Católicos, ${ }^{3}$ que nos permitam expressar a diversidade interior ao Grupo de Vereadores Católicos.

\footnotetext{
${ }^{2}$ No decorrer do trabalho de campo, o relevo do Grupo de Vereadores Católicos atuante na Câmara Municipal de Porto Alegre foi sendo acrescido pelas constantes referências que surgiam em relação à existência de tal entidade no campo político local.

${ }^{3}$ Nas descriçôes dos sujeitos da pesquisa apresentadas neste texto, ora um ora outro destes campos de observação ganha maior relevância, de forma que a sorte dos dados varia de descrição para descrição, mas sempre em função da caracterização da diversidade interior ao Grupo de Vereadores Católicos.
} 
Em termos metodológicos, o trabalho compreende etnografia nas campanhas de dois desses vereadores, entrevistas semi-estruturadas com os quatro e entrevistas do mesmo tipo com dois clérigos ligados ao Grupo.

Cabe a ressalva de que não interpretamos os processos aqui expostos a partir da imagem do "retorno" da religião ao espaço político, mas, sim, como possibilidades de rearticulações entre dimensões (religião e política) que nunca tiveram seu elo definitivamente desconectado, porém, sucessivamente reordenado (Buriti, 2000). A ênfase deste texto é etnográfica. Procuramos abordar as particularidades que cada vereador imprime em sua narrativa em torno das imbricaçôes entre religião e política. De forma a reconstituirmos, textualmente, o entrelaçamento da trajetória pessoal, da dimensão religiosa e da dimensão política que cada vereador articula. Assim, tecendo o ponto em que estas narrativas revelam uma diversidade de percepçôes, tanto político-ideológicas quanto religiosas, atualizando-se em sua participação enquan to "vereadores católicos".

Todavia, o exercício aqui proposto não se encerra na revelação da diversidade de percepções e posicionamentos políticos e religiosos no contexto do Grupo de Vereadores Católicos. Na parte final do texto, exercitamos uma certa "dinâmica do olhar" em que, salientando as semelhanças entre os aspectos que pareceriam, a um primeiro olhar, heterogêne os e as diferenças naquilo que pareceria homogêneo, iniciamos um trabalho que, dadas a complexidade de seu tema e a amplitude do recorte, poderia ser mais profundamente desenvolvido em trabalhos posteriores. Esboça-se aqui, de certa forma, uma "grade de in teligibilidade" "para a compreensão do processo pelo qual tal diversidade de percepções, revelada nas narrativas dos políticos, possa ser acomodada no interior de um mesmo grupo com referência no catolicismo.

${ }^{4}$ Sentido que Marcio Goldman (2003) dá à teoria etnográfica, que "tem o objetivo de elaborar um modelo de compreensão de um objeto social qualquer (linguagem, magia, política) que, mesmo produzido em e para um contexto particular, seja capaz de funcionar como mat riz de inteligibilidade em ou tros con textos." (Goldman, 2003, p. 460). 


\section{O GRUPO DE VEREADORES CATÓLICOS}

Dada a relevância que o Grupo de Vereadores Católicos ganhou no decorrer do trabalho, faz-se necessária uma caracterização mais profunda, de forma a podermos visualizar o posicionamento da Igreja Católica no que se refere à política partidária, no contexto em estudo.

O Grupo de Vereadores Católicos foi fundado em 2002 por dom Antônio Cheuiche,então responsável pelo Vicariatoda Culturana Arquidiocese de Porto Alegre. Segundo o padre Roberto Paz, atual coordenador do Grupo, "a cultura supõe justamente a encarnação do Evangelho nas diferentes categorias, segmentos da população". Assim, imbuído da perspectiva de "evangelização dos ambien tes", 5 dom Antônio, expressando a preocupação da Igreja Católica com a presença nas Assembléias, tanto estadual quanto municipal, começou um trabalho na Assembléia Legislativa do Rio Grande do Sul. Daí originou-se o Grupo de Parlamentares Católicos, formado pelos deputados. O Grupo de Vereadores Católicos é justamente o desdobramento dessa proposta na Câmara Municipal de Porto Alegre, tendo, em sua fundação, contado com os vereadores Ervino Besson (PDT - Partido Democrático Trabalhista), Aldacir José Oliboni (PT - Partido dos Trabalhadores), Beto Moesch (PP - Partido Progessista), Maria Celeste (PT), Humberto Goulart (PDT), Adeli Sell (PT), João Bosco (PDT), Carlos Alberto Garcia (PSB - Partido Socialista Brasileiro), Elói Guimarães (PTB - Partido Trabalhista Brasileiro), Clênia Maranhão (PPS - Par tido Popular Socialista), Cassiá Carpes (PTB) e João Carlos Nedel (PP). ${ }^{6}$

\footnotetext{
5 Padre Roberto Paz aponta como uma das inspiraçōes para a criaçáo deste movimento, o “jubileu dos políticos" celebrado pelo papa no ano 2000: "Houve sim, com toda essa preparação do jubileu, a necessidade de voltar-se para as elites dirigentes, e a evangelização dos ambientes. E dentro disso, o que caracterizou sempre a arquidiocese de Porto Alegre, à diferença da CNBB, foi a presença de dom Antonio, e dom Antonio tem mais de 20 anos aqui. Dom Antonio foi um dos precursores da chamada evangelização da cultura e dosambientes."

${ }^{6}$ Além dos fundadores, padre Roberto Paz cita como atual participante Maristela Maffei (PT). Alguns outros vereadores, não citados durante as entrevistas, têm presença mais esporádica.
} 
O Grupo de Vereadores Católicos tem abrangência arquidiocesana, sendo composto também por vereadores de outros municípios vizinhos, que são parte da Arquidiocese de Porto Alegre. Segundo padre Roberto Paz, o Grupo, apesar de ser de confissão católica, tem uma proposta ecumênica. Mas, ao menos os vereadores da Câmara Municipal de Porto Alegre vinculados ao Grupo se identificam mais propriamente com a Igreja Católica.

[...] se trata não de ter uma articulação em termos de atividade partidária, mas de conhecer a doutrina social e também uma espiritualidade cristá. Por isso celebramos sempre com os deputados estaduais e com os vereadores o dia do político católico, que é o dia justamente de São Tomás Moro. (Padre Roberto Paz)

O caráter político do Grupo não gira em torno de fazer, nas palavras do padre Paz, "um patrulhamento para defesa institucional da igreja", mas de oportunizar um encontro entre políticos para o exercício do que chama de "cultura política de comun hão". Nesta perspectiva, as reuniões são divididas em dois momentos: o primeiro de rezas e reflexões; e uma segunda parte com discussões sobre algum tema previamente estabelecido. Portanto, essa divisão da reunião denota a proposta de conformação do Grupo, tanto como um espaço, nas palavras de padre Paz, de "celebração da fé", como um "espaço de diálogo, um espaço onde a doutrina social cristã possa fermentar e possa até viabilizar projetos comuns".

Como exemplo de ações concretas que vêm mobilizando o Grupo, citamos a Campanha da Fraternidade, a qual tem recebido o apoio de vereadores de diferentes partidos através da iniciativa conjunta do Grupo de Vereadores Católicos.

Nós fazemos nosso planejamento em função de uma... para evangelizar. Dentro do que é a evangelização essa terceira prioridade que é a participação na construção de uma sociedade mais justa e mais democrática. Essa tradição da cidadania num sentido pleno. (Padre Roberto Paz) 
A faceta política, que a Igreja Católica assume através de instânciascomo o Grupo de Vereadores Católicos e o Grupo de Parlamentares Católicos, não traz expressa uma disposição à disputa no campo político; aproxima-se mais do fomento à discussão sobre o fazer político, suas bases éticas e a relação entre os compromissos políticos e a doutrina social cristã. Enfim, iniciativas como essas apontam uma tendênciadentro da Igreja Católica:a auto-atribuição da "missão" de evangelizar a cidadania e a cultura democrática. Dom Antônio Cheuiche deixa clara esta distinção entre mobilizações políticas direcionadas à disputa e a proposta desses grupos católicos nas assembléias: "O Grupo de Políticos Católicos não é um partido, não é uma frente, não é um braço da igreja [...] é um espaço onde os deputados se reúnem para rezar, refletir sobre a palavra de Deus e sobre os deveres dos políticos cristãos".

Que a pluralidade ideológica presente no campo político seja incorporada no Grupo é uma das preocupaçóes dos clérigos envolvidos no processo de composição dos membros. Como afirma padre Roberto Paz: "Na verdade, nós tratamos de combater, tanto dom Antônio como a minha pessoa, a identificação do conceito 'só existe um vereador católico: eu’”. É rechaçada, portanto, a idéia de um "monopólio", como atesta Roberto Paz, em torno de uma imagem ideal e inequívoca do "vereador católico". Os clérigos compuseram o Grupo de forma a "ampliar o conceito", expressando, neste ponto, uma clara preocupação em incluir a diversidade de concepções políticas e religiosas que se atualizam entre os vereadores identificados com a Igreja Católica na Câmara Municipal de Porto Alegre. É justamente no intuito de expor essa diversidade característica ao Grupo de Vereadores Católicos que, neste texto, aprofundamos os casos particulares de quatro vereadores: Ervino Besson (PDT), Beto Moesch (PP), Maria Celeste (PT) e João Carlos Nedel (PP); cada qual evidenciando, em sua narrativa, diferentes possibilidades de articulação entre religião e política.

\section{ERVINO BESSON}

Ervino Besson reelegeu-se pela terceira vez (entre quatro candidaturas) 
nas eleições municipais de 2004. Integrante, desde sua entrada na política partidária, do PDT (Partido Democrático Trabalhista), alcançou o total de 6.459 votos, garantindo a margem necessária para assumir o mandato 20052008 na Câmara Municipal de Porto Alegre.

De ascendência marcadamente italiana, Ervino criou-se no interior do município de Casca (RS) em uma família de "colonos", como ele classifica. Segundo Ervino, a sua era uma "família muito católica, católica praticante", que vivia da pequena produção rural. As atividades na ig reja preenchiam o espaço do fim-de-semana, no qual seu pai organizava leilóes nas igrejas da localidade de Casca.

Assim, Ervino socializava-se no ambiente da comunidade católica, tendo, desde já, sua identidade religiosa marcada pela dimensão familiar e comunitária. Foi alfabetizado em uma "brizoleta" com cerca de seis alunos, instalada nas terras de seu pai. Em sua trajetória, isso teria implicações definitivas, pois, desde então, a doutrina trabalhista tomava espaço em sua vida, mostrando sua eficácia através da realização de uma das prioridades trabalhistas: universalização da educação.

Por dificuldades econômicas advindas do falecimento de sua mãe, a família Besson se mudou para o interior de São Leopoldo. Lugar que, para ele enquanto jovem, não proporcionou boas oportunidades de emprego, posto que, em 11 de agosto de 1961, Ervino e seu irmão mais velho mudaram-se definitivamente para Porto Alegre, vindo a trabalhar no Secretariado de Ação Social da Arquidiocese de Porto Alegre. Nessa sua ocupação dentro da Igreja Católica, Ervino começou um trabalho junto a comunidades onde a Arquidiocese desenvolvia trabalhos de cunho social. Destaca-se, em sua narrativa, a participação ativa na construção da Cidade de Deus. ${ }^{8}$

\footnotetext{
${ }^{7}$ Escolas de pequeno porte espalhadas pelo interior do estado do Rio Grande do Sul para proporcionar o estudo primário nas comunidades afastadas dos centros urbanos. Obras da política educacional na gestão do governador Leonel Brizola (1958-1962), fundador do PDT.

${ }^{8}$ Conjunto populacional construído por mutirôes para a edificação de casas populares.
} 
Desse contexto, emergiria como candidato ao pleito municipal pela primeira vez.

E a gente fez um trabalho muito forte na comunidade, mas sempre ligado à religião, sempre ligado à religião católica. Em 88, umas pessoas da comunidade, da liderança da comunidade, dentro da construção da Cidade de Deus, que eu fui um colaborador na construção dessa entidade. Algumas pessoas me lançaram candidato a vereador. Bom, aí me candidatei a vereador e me elegi em 88, assumi em 89 até 93 [...] Eles [comunidade católica] me lançaram.

Podemos interpretar que a "porta de entrada" de Besson na política partidária se deu através da religião, pois sua atuação no trabalho comunitário foi direcionado à primeira candidatura, obtendo sucesso. Todavia, o vereador relata que, depois de sua eleição, parte da comunidade católica passou a vê-lo como um diferente, estranhando-o em sua nova condição enquanto político. Como se, ao entrar para o ramo da política, Ervino deixasse de ser plenamente religioso. Apesar dessa visão dicotômica presente em alguns grupos católicos e clérigos, Besson nunca se sentiu exterior à igreja, sempre praticando os sacramentos e participando das atividades para as quais era requisitado.

A comunidade, tudo muito ligadoà religião. Mas aí teve um problema, quando eu me elegi vereador, a religião [...] Alguns sacerdotes já não me viam mais como colaborador, me deram um gelo, sabe? Aí eu não tinha mais aquela penetração que eu tinha na igreja, porque alguns... pessoal mais ligado à igreja, juntamente com alguns padres já me via como um político. [...] porque eu nunca pensei que ia enfrentar um problema de uma religião, que eu sou católico de berço... que a igreja me daria outro tratamento... que eu tinha um envolvimento familiar junto com a igreja, e depois como vereador já tive um tratamento diferenciado. Mas eu nunca deixei de exercer minha religião católica. E nunca deixei de colaborar com a igreja quando era chamado. Mas o próprio segmento da igreja me distanciou um pouco. 
Sua entrada para a política marcou uma rearticulação na relação com o religioso. Ele, que era católico "de berço", que tinha o traçado de sua vida ligado à participação na comunidade católica, sentia, neste estranhamento que lhe direcionavam alguns membros da Igreja Católica, uma quebra com sua condição anterior. Certamente, não uma ruptura definitiva, pois a identidade católica permanecia, mas uma rearticulação de olhares marcada pela dicotomia entre religioso e político. Besson teria, agora, em suas palavras, um "outro tratamento", pois ele era visto como de um "outro patamar".

Quanto à sua escolha partidária, afirma estar marcada pela leitura da doutrina trabalhista. Em muito influenciado por sua experiência como estudante de uma "brizoleta" no interior, a partir da qual começou a acompanhar a "trajetória que representou o trabalhismo", em sua atuação no cenário político brasileiro e, principalmente, rio-grandense. Besson acredita que o PDT "ainda fará muita coisa por este país", e por essas razões se filiou e permanece representando esse partido na Câmara dos Vereadores de Porto Alegre.

Em sua tentativa de reeleição, em 1992, não conquistou a vaga por 169 votos. Já nas eleições municipais de 2000, voltou a obter êxito, garantindo seu segundo mandato como vereador (2000-2004).Nesse período, observou uma nova mudança no tratamento que a Igreja Católica lhe dispensava.

[...] alguns padres, até por força de pessoal da comunidade sentiram que estavam cometendo um equívoco. Até porque eu faço parte de um grupo de políticos católicos. E o dom Dadeus, muito inteligentemente, largou umas cartilhas. E hoje reverteu o quadro.[...] Acho que a igreja mudou muito e começou a ouvir os próprios representantes, não só do meu partido, mas de outros partidos.

A sua inserção no Grupo de Vereadores Católicos marca, para Besson, uma revisão da parte da igreja, que se havia distanciado dele quando se tornara vereador. Essa iniciativa de articular os políticos católicos, juntamente com o lançamento das "cartilhas", " delineia uma outra forma da

9 "Cartilh aEleitoral 200 2" e "Eleições Mun icipais 2004”, escritas por dom Dadeus Grings, arcebispo de Porto Alegre, para a orientação de discussões políticas nas paróquias durante as campanhas eleitorais. 
Igreja Católica se relacionar com o político partidário, reverberando em setores católicos que até então dispunham-se a afastar a política partidária do exercício religioso; favorecendo, inclusive, a articulação dos vereadores com bases católicas durante o mandato: "No início tava meio truncado. Mas hoje abriu esse leque, esse nosso grupo católico conseguiu dar abertura nisso aí; e eu quero aprofundar, quero estar junto e trabalhar, fortemente, junto com essas comunidades".

Besson destaca a importância da família enquanto suporte para o político em seu desgastante cotidiano, apontando como um traço comum entre ele e seus colegas no Grupo de Vereadores Católicos justamente essa presença da dimensão familiar cristã em suas vidas.

São pessoas que familiarmente eles sempre tiveram uma estrutura, o alicerce vivo que é a família. [...] A política não é fácil, nosso trabalho é desgastante.[...] A família nesses momentos, o cristianismo, a crença que tem que alicerçar o político.[...] Eu também tenho isso na minha casa, o Nedel tem, o Beto Moesch também tem, a Maria Celeste também tem...

Segundo o vereador, a experiência no catolicismo traduz-se no trabalho político em "uma disciplina", "uma dureza maior", conferindo uma certa disposição ao católico em não aspirar ao campo político visando ao benefício pessoal, na medida que "são religiosos, que não tem aquela ganância”. Quanto aos projetos em seu novo mandato (2004-2008), Besson tem como metas principais a diminuição do custo das passagens para estudantes do primeiro grau em Por to Alegre - dentro do princípio trabalhista de universalização da educação - e a criação de um conselho com representantes de diversas secretarias municipais, como forma de agilizar os trâmites burocráticos na Capital.

\section{BETO MOESCH}

O vereador Beto Moesch nasceu numa família onde religião e política se faziam presentes, em virtude de ser a sua uma família tradicionalmente 
católica - dando-lhe "uma formação eminentemente cristã, solidária" - e de seu pai, Guido Moesch, que depois viria a ser deputado estadual e federal, atuar, em 1965, como chefe de gabinete do governador do Rio Grande do Sul, Ildo Meneghetti .

Beto possui dois tios padres, um materno e um paterno, o que revela a ligação com a tradição católica presente nas duas famílias, sendo seu irmão mais velho, Eduardo Moesch, também padre. O convívio nesse meio fez com que o vereador criasse raízes na comunidade cristã, tornando-se praticante da religião católica. Beto Moesch confirmou alguns sacramentos como Batismo e Crisma, fez catequese, primeira comunhão, participou e foi dirigente de grupo de jovens (especialmente o CLJ ${ }^{10}$ ). Atualmente, tem a prática religiosa de ir à missa e rezar.

Tendo formação acadêmica em Direito pela Universidade Federal do Rio Grande do Sul, Beto desenvolveu trabalhos mais voltados para a questão ambiental, tornando-se consultor em Direito e Legislação Ambiental. Coordenou, inclusive, a elaboração de leis ligadas a esse tema, como, por exemplo, o Código Estadual do Meio Ambiente/RS; a partir da Lei, que institui o Sistema Estadual de Proteção Ambiental, cria, também, a Política, o Conselho e o Fundo Estadual do Meio Ambiente.

A formação na doutrina social cristã é marcante em sua trajetória, segundo ele, contribuindo fortemente para a compreensão política que projeta em sua atuação como vereador. Nesse seu aprendizado da doutrina social cristã, Moesch participou como representante brasileiro de congressos de democratas cristãos na América Latina, onde discutiram políticas sociais e econômicas, baseadas na doutrina social da Igreja Católica. Participa de entidades de caráter cristão como a Associação dos Juristas Católicos (AJC), como conselheiro, e da Associação dos Dirigentes Cristãos de Empresa (ADCE). Durante um almoço nesta entidade, Moesch proferiu um discurso expressando a diferença en tre o "político cristão" e os demais:

${ }^{10}$ Curso de Liderança Juvenil: movimento católico jovem do Rio Grande do Sul (fonte: www.catolico.org.br). 
Eu sempre disse que existe uma grande diferença entre o político cristão e o não cristão. O político cristão é aquele que tem fé, que sabe que Deus está ao lado dele e sempre quando estiver agindo ele sabe da força que tem e da responsabilidade que tem. Essa é a grande diferença do político cristão para o político não cristão. ${ }^{11}$

Em 1996, lançou a sua primeira candidatura para a vereança de Porto Alegre, pelo então PPB, ficando como primeiro suplente, com 3.519 votos. Nas eleiçôes de 2000, conseguiu se eleger com 6.295 votos (também pelo PPB); e no pleito de 2004, com a sigla de seu partido modificada para PP (Partido Progressista),obtém a reeleiçãocom um aumento significativo quanto ao número de eleitores; foi o quinto mais votado, com 11.215 votos.

Sua trajetória na Câmara de Vereadores de Porto Alegre é embasada nos "princípios cristãos", tendo sempre como luta principal a defesa do meio ambien te, que, segundo ele, é "tudo". Trabalhar com o meio ambiente, diz, é "trabalhar com a qualidade de vida, é planejar algo, então tudo é meio ambien te, não só a natureza”. Líder da ban cada do Partido Progressista (PP), ex-presidente e atual vice-presidente da Comissão de Saúde e Meio Ambiente da Câmara Municipal, Moesch é autor de diversas leis do município de Porto Alegre, incentivan do a proteção ao meio ambiente, ao patrimônio histórico e ao bem-estar dos animais.

$\mathrm{O}$ vereador ressalta sempre a importância da família. A sua, inclusive, sempre se fazia presente em seus compromissos de campanha, acompanhando e participando de eventos como almoços e chás nas paróquias. Seus pais atuavam na distribuição de material como os "santinhos" e até o representavam em alguns compromissos.

No que se refere à articulação entre religião e política, segundo o vereador, os princípios e valores cristãos vêm da educação que teve, da base

\footnotetext{
${ }^{11}$ Fragmento de discurso proferido na ocasião do almoço da ADCE em homenagem a dois de seus membros eleitos (Beto Moesch e João Nedel) nas eleições municipais de 2004. Em 07 de outubro de 2004.
} 
familiar, e do convívio no meio religioso. Então, por conta disso, para Beto, são valores interiorizados, que se manifestam no seu modo de viver e de agir, incluindo a política. Nesse sentido, notadamente a política e a religião estariam interligadas por um fio condutor formado pelos princípios éticos, dos valores morais do "político cristão", como ele se classifica.

O meio ambiente, sua principal bandeira, estaria diretamente relacionado à doutrina cristã. Posto que,

defender o meio ambiente é evangelizar, quem defende o meio ambiente, quem faz educação ambiental, está evangelizando [...] então é importante que o ecologista entenda a doutrina social cristã, e o cristão entenda os princípios ambientais,porque estão irmanados e eu sempre busquei inspiração na fé, na religião, para também fazer o trabalho em defesa do meio ambiente.

Quanto ao seu discurso "político-religioso", observamos que em situações distintas, Moesch acessa diferentes discursos, pois, segundo ele, "além de católico" e advogado, é ambientalista e surfista. Esse dinamismo lhe permite a circulação em diferentes espaços, articulando-se com diferentes públicos.

não acho nada antiético, pelo contrário,eu me acho na obrigação no momento em que eu me considero um vereador católico, eu buscar espaços com os católicos, então eu vou à ADCE e à AJC fazer campanha, entregar santinhos, na missa eu vou com o boton [...] Então eu faço campanha no meio católico, mas eu faço em todos os meios, não só nas igrejas.

Beto Moesch também se articula com a hierarquia da igreja, mantendo contato com diversos padres de Porto Alegre e, em tempos de eleição, enviando correspondência como pedido de votos.

A preocupação de Beto Moesch com a articulação entre religião e política na esfera pública traduz-se em eventos como o movimento dos vereadores católicos, e o ato infra-religioso que ele promove na semana do meio ambiente. Em relação ao Grupo de Vereadores Católicos, relata que foi procurado por dom Antonio Cheuiche para ajudá-lo a montar um grupo 
com membros da Câmara Municipal de Porto Alegre, que fossem "católicos praticantes", independentemente de adesão partidária. Diante do que chama de "desafio", o vereador aceitou, vindo a contribuir para a formação, em 2002, do Grupo de Vereadores Católicos: formado por membros de diferentes partidos, com diferentes ideologias, mas unidos pelo fato de terem uma "base cristã".

[...] ser um praticante da fé, ou seja, não é dizer que antes de fazer um pronunciamento na tribuna tu vais fazer um sinal da cruz, um modo de evangelizar modernamente não é isso... mas no meu pronunciamento eu ter uma base cristã, no sentido de que eu não preciso citar Deus.

E, imbuído da compreensão do "modo de evangelizar modernamente", Beto assume sua função de político como um lócus preferencial nesse exercício cristão, na medida que "... toda a pessoa é ou pode vir a ser um potencial agente evangelizador, principalmente um político”.

Beto interpreta sua entrada na política, e suas sucessivas candidaturas, como "chamados" em que é inspirado a ocupar cargos parlamentares. Assim, no final de seu discurso na ADCE em 7/10/2004, ocasião em que era homenageado pela sua recente reeleição para a vereança de Porto Alegre, Beto relatou o novo "chamado" que havia recebido, anunciando seus planos próximos:

[...] por ter me reelegido com 11.215 votos, eu recebi o chamado, porque não são só os padres, que recebem os chamados de Deus. Todas as pessoas recebem os chamados, eu recebi um chamado para entrar para a política, e recebi um chamado para que a $\mathrm{ADCE}$ não tenha apenas representante na Câmara de Vereadores, mas também na Assembléia Legislativa do Estado do Rio Grande do Sul [aplausos]. Sou candidato a deputado estadual.

\section{MARIA CELESTE}

A forma de Maria Celeste fazer política, segundo ela, se diferencia da 
maneira "tradicional"; sua proposta gira em torno de estar em contato direto com a população, mantendo, inclusive, espaços de diálogo abertos durante todo o mandato, e não apenas no período eleitoral.

Sua trajetória em direção à política começou no movimento de base da Igreja Católica. Primeiramente, como catequista na paróquia das proximidades de sua casa, na Vila Santa Rosa (Porto Alegre); posteriormente, nos "grupos de jovens da igreja". Na escola paroquial São Francisco, ${ }^{12}$ foi líder estudantil. Maria Celeste caracteriza a "questão da religião" nos inícios de sua "militância política" assim:

[...] minha trajetória política, a religião é muito presente, muito forte, na medida em que fui me constituindo como liderança enquanto adolescente, enquanto jovem participando do movimento de base da Igreja Católica, a partir daí expandindo nossos olhares e os nossos rumos para outras tarefas.

Através de seu trabalho voluntário em uma creche ligadaà Igreja Católica, MariaCeleste voltou-se para a assistênciasocial, tendo como foco de suas ações a questão da criança. Depoisde um período em que se dedicou à maternidade - aspecto em que destaca a importância do acompanhamento próximo da mãe na criação dos filhos -, ela passou a assumir maiores responsabilidades neste trabalho da creche vinculada à Igreja Católica; afirma que "....a religião e a minha militância, e de trabalho mesmo, foi uma coisa muito unida”. Maria Celeste foi a primeira coordenadora leigadessa instituição, que atendia 300 crianças, e cujo planejamento e ação eram embasados na Teologia da Libertação. ${ }^{13}$

\footnotetext{
${ }^{12}$ Atual Instituto São Francisco.

${ }^{13}$ Segundo Julia Miranda, "O cristianismo de libertação deu origem a uma teologia portadora de um projeto político: transformar radicalmente a sociedade, de forma a instaurála em novas bases: mais justas, solidárias e igualitárias. Trata-se, nesse caso, de um discurso elaborado com recurso às ciências sociais; teológico mas de explícitas pretensões políticas, que busca justificar a ação transformadora - em alguns casos revolucionária identificada como cristã, além de lhe servir de orientação. Para tanto, apóia-se num movimento que cria e reativa tecidos comunitários, as Comunidades Eclesiais de Base." (Miranda, 1999, p. 127).
} 
[...] muita influência, a Teologia da Libertação foi fundamental.[...] Fazíamos o planejamento participativo da instituição, todo esse trabalho muito ligado à Teologia da Libertação. [...] Então, a gente teve muita influência na literatura, na questão Leonardo Boff. Nós e os demais padres, enfim, trabalhavam muito essa questão conosco. E isso nos levou a ter uma militância mais forte na área da assistência social.

A atuação nessa instituição a encaminhou ao cargo de conselheira tutelar, através de um grupo ativo, inclusive na pastoral da juventude da Igreja Santa Rosa de Lima. Esse mesmo grupo, percebendo a necessidade de buscar um espaço de atuação mais representativa, objetivando a defesa da causa da criança, ingressou, juntamente com Maria Celeste como candidata, na disputa por uma cadeira na Câmara Municipal de Porto Alegre, nas eleiçôes de 2000. Maria Celeste foi eleita vereadora pela primeira vez nessa ocasião, obtendo 7.124 votos, a $12^{\text {a }}$ vereadora mais votada do município. No pleito municipal de 2004, garantiu a permanênciano cargo de vereadora, obtendo 9.498 votos. Tal crescimento se deve, segundo a vereadora, ao trabalho realizado nas comunidades que são sua base eleitoral.

Ela relata que ingressou no Partido dos Trabalhadores (PT), por ser o partido em que encontrava maior identificação com suas "lutas", tendo sempre sido "simpatizante, mas simpatizante que assume, que vai e faz campanha, que corre atrás, que elege vereador”. No início, Maria Celeste encontrou dificuldades com alguns de seus eleitores, católicos mais conservadores, que, segundo ela, acreditam que PT é sinônimo de política radical; em suas palavras, "um bando de malucos, que vão para rua, baderneiros". Mas ela afirma que com o tempo, está desmistificando essa visão negativa sobre a forma de fazer política do PT, mostrando que há uma outra forma de se fazer política, que é trabalhando na comunidade com as bases, tendo um "olhar diferenciado".

Como vereadora, Maria Celeste participa do Grupo de Vereadores Católicos da Câmara Municipal de Porto Alegre. Foi convidada a integrar esse fórum por dom Antônio Cheuiche, que já conhecia a sua identificação católica e sua atuação na paróquia Santa Rosa de Lima. Para Maria Celeste, a 
finalidade do grupo de vereadores católicos é construir uma "nova relação política en tre os partidos", voltada para a construção de uma "política do bem comum”. E, dentro dos propósitos in ternos do Grupo, criar laços entre os vereadores, não obstante divergências partidárias e político-ideológicas.

[...] o fórum vem também com essa característica de poder ter relação com pessoal, apesar das idéias e divergências partidárias. Então, construir essa relação entre os vereadores de diversos partidos é muito complicado e muito complexo, mas o objetivo maior é isso, tu construíres uma política que tu consigas dialogar levando a proposta da solidariedade, da fraternidade, do bem comum acima de tudo.

Há, portanto, o ensejo de uma superação daquilo que Maria Celeste chama de "política tradicional do ranço". A própria diversidade de concepções em torno da religião, presente no interior da Igreja Católica, também se atualiza no Grupo; estando, segundo Maria Celeste, presentes desde conservadores, crentes de que o Grupo de Vereadores Católicos deva ter caráter mais próximo de um grupo de oração, até políticos ligados a uma concepção mais próxima da Teologia da Libertação - entre os quais Maria Celeste se inclui. A tendência desses é a proposta do Grupo como um fórum de discussões políticas, con textualizando a religião como "in strumento" para a "política do bem comum", construindo uma proposta mais direcionada a posicionamentos e ações concretas. Como exemplo de iniciativa originada nas discussóes do Grupo, pode ser citado o projeto "Brin cando sem armas". ${ }^{14}$

Diante desse campo plural instituído no Grupo de Vereadores Católicos, segundo a vereadora, o que estabelece a unidade é a "fé", que pode ser exercida através do respeito mútuo na relação entre as diferentes percepções religiosas e político-ideológicas.

\footnotetext{
${ }^{14}$ Numa reunião do Grupo de Vereadores Católicos foi lançada a idéia da necessidade de trabalhar com a questão da infância em Porto Alegre. Então, surgiu o "Brincando sem Armas" - projeto no qual crianças de comunidade carentes trocavam armas de brinquedo por outros brinquedos pedagógicos -, como forma de agir diretamenten a comunidade; sendo este projeto produzido coletivamente pelos vereadores.
} 
O que nos dá unidade é a fé, eu acredito que é a fé, o respeito que a gente tem mesmo pelas idéias diferentes de cada um... a fé é o que nos dá uma unidade maior. E nós estamos ali porque nós estamos querendo algo melhor para todos.

Apesar de nãoter realizado campanhanas paróquias, elaacreditaque conseguiu uma grandevotação com os membros da Igreja Católica. Confirma que o "pessoal da igreja", principalmente os participantes do ECC (Encontro de Casais com Cristo), lhe deram um forte apoio no decorrer da campanha.

Essa sua estreita relação com a Igreja Católica, por vezes, pode adquirir tons mais conflitivos. Em alguns de seus posicionamentos, notadamente em torno de questôes polêmicas no catolicismo, como a livre orientação sexual e o aborto, Maria Celeste diverge das opinióes sustentadas pela hierarquia católica. Para seu embasamento, a vereadora busca pesquisar os temas polêmicos, não reproduzindo irrefletidamente os posicionamentos da ortodoxia católica, mas sempre atenta ao conteúdo dos evangelhos.

Eu fico pensando naquela frase de Jesus que ele sempre defendeu as minorias. [...] Bom, penso que assim como Jesus defendia as minorias naquela época e em todo o evangelho ele prega isso, e eu acho que nós temos esse dever como católicos de defender, sim! De lutar contra o preconceito, contra a discriminação e fico muito tranqüila com relação a isso.

Destaca como valores fundamentaisno exercício de seu dever,enquanto parlamentar, a verdade e a ética, que vêm de sua formação religiosa; tendo esses princípios como nortes em suas ações na vereança, Maria Celeste pretende continuar neste mandato sua proposta de "aproximar a Câmara de Vereadores do povo", constituindo iniciativas que, mais que projetos de lei, são "projetos de vid a".

\section{JOÃO CARLOS NEDEL}

Reeleito para seu terceiro mandato consecutivo como vereador pelo 
Partido Progressista, Nedel tem sua trajetória de vida profundamente marcada pela condição de católico. A estruturação de valores pessoais e princípios que norteiam sua atuação política (em geral caracterizada como de um cristão conservador), os espaços sociais a partir dos quais construiuse como "homem político", bem como o lócus a partir de on de projeta com maior intensidade sua legitimidade como representante de determinado grupo na atualidade, têm direta relação com sua participação na Igreja Católica, sua doutrina e a comunidade que com ela se identifica. É justamente neste contexto de articulações e interfaces entre religião e política que se situam sua forma de campanha e sua atuação na Câmara de Vereadores. E, seguramente, por esta sua reconhecida imagem pública que Nedel foi chamado a ser um dos fundadores, junto com representantes da hierarquia católica, do chamado Grupo de Vereadores Católicos.

Nascido em berço católico, Nedel relata ter se destacado como liderança política desde a juventude, atuando em diversos movimentos, especialmente ligados ao catolicismo como Os Cruzados, a formação do Partido Democrata Cristão no Estado, e a Associação dos Dirigentes Cristãos de Empresas (ADCE), onde teria ouvido palestras sobre o compromisso social e político do cristão, as quais lhe teriam convencido a entrar na política. $\mathrm{Na}$ verdade, segundo ele, teria entrado na política "para evangelizar esta área, como uma missão", uma vez tratar-se de um ambiente "que não estava sendo iluminado pelo Evangelho" (Oro, 2001, p. 37).

[...] testemunhar com trabalho a doutrina social cristã, que aprendemos aqui na ADCE, com aquela palestra: "o compromisso político do cristão" e aquela palestra o "compromisso social do cristão". A minha decisão de entrar na política foi após um encontro da ADCE.[...] vim a conhecer quais as minhas responsabilidades sociais e políticas. ${ }^{15}$

Formado em Ciências Contábeis, trabalhou com diversas empresas e também na área financeira e de mercado de capitais onde atuou por 30

\footnotetext{
${ }^{15}$ Idem 5.
} 
anos. Em 1973 tornou-se Ministro da Eucaristia, e tem atuado junto à igreja em um sem número de atividades, desde conselhos arquidiocesanos até como palestrante em cursos para a comunidade. Em sua primeira eleição para vereador, em 1996, foi eleito com 5.107 votos, aumentando para 6.039 o número de eleitores no ano de 2000, eleições nas quais estima que $60 \%$ dos votos tenham sido provenientes de católicos, especialmente das paróquias em que tem atuado (Oro, 2001, p. 37). Na eleição deste ano foi escolhido por 6.787 pessoas. Quando se referindo à relação entre sua trajetória política e sua condição religiosa, prefere sempre demarcar a idéia de que a relação com a Igreja Católica lhe foi fundamental, primeiramente pela formação moral que lhe teria legado, e secundariamente, por ser a base fundamental sobre a qual projeta sua figura de representante. Porém, busca afastar a idéia de "macular" suas relaçôes religi osas com a figura de "homem da política", no sentido de que, quando se apresenta como católico, demarca apenas a condição de fiel, não de político, quando muito de líder dentro do próprio movimento. Entretanto, sua performance como político, sim, contempla a figura do religioso, acessando noçôes ligadas a este imaginário, explícita ou tacitamente.

Suas campanhas têm sido marcadas por uma forte articulação com a condição religiosa. Embora, diferentemente de anos anteriores, quando se ap resentava na televisão como "cristão na palavra e na ação", na campanha de 2004, o vereador parecia buscar,para o público mais amplo, em outdoors, placas e nas inserções televisivas a imagem de um político atuante, comprometido com valores como "a família, o emprego e o desenvolvimen to", sem apresentar diretamente sua condição religiosa. Nedel acessa, assim, valores idealmente seculares de forma direta e, tacitamente, valores religiosos. No mesmo sentido, apresentava-se como o vereador com maior número de presenças em sessões plenárias e em comissões na última legislatura, bem como "o campeão em ações legislativas", o que lhe justificaria o slogan de "um vereador que trabalha".

Todavia, sua articulação com as comunidades cristãs (como ele mesmo se referia, ampliando o leque para além do catolicismo) foi decisiva para a vitória eleitoral. $\mathrm{O}$ vereador mantinha uma intensa agenda de participação 
em eventos ligados à igreja, na maior parte das vezes apresentando-se não na figura de candidato, mas de fiel exercendo sua prática de fé. $\mathrm{O}$ papel da divulgação em sua campanha, Nedel atribuía aos "multiplicadores", como eram chamados. Assim, novamente, apresentava-se como homem de princípios quando em um contexto idealmente secular, mas não como político nos espaços tradicionais do campo religioso. Segundo ele, isto denotava um cuidad o para não "agred ir as pessoas" - preocu pação expressa repetidas vezes - e não aparentar estar usando a religião para se promover na política. Para Nedel, essa atitude discreta seria importante porque, "neste público, ao se perder a credibilidade, é muito difícil recu perá-la”.

Em sua atuação como vereador, é reconhecido por trazer a marca de um cristão atuante e conservador. Caracteriza-se pela defesa dos valores tradicionais da Igreja Católica, e pela demarcação constante que faz de suas diferenças com os políticos ligados ao Partidodos Trabalhadores.A marcante utilização que faz dos chamados "Pedidos de Providên cias", ${ }^{16}$ o diferencia dos demais vereadores. Entre 2001 e 2003, realizou 3.128 delas, significando cerca de $40 \%$ do total produzido na Câmara de Vereadores.

Eu trabalho atendendo as necessidades da população. Especialmente as que têm mais necessidades.[...] Eu quero continuar trabalhando atendendo as necessidades dos mais carentes. O ano passado eu fiz mais de mil Pedidos de Providên cia neste sentido de encaminhar as peque nas solicitações das comunidades. E esse ano fiz por volta de oitocentos. ${ }^{17}$

Esse tipo de atuação parlamentar se coaduna com sua concepção religiosa, que, segundo o próprio vereador, levou-o a integrar o grupo dos

\footnotetext{
${ }^{16}$ Medidas voltadas para a solução de problemas pontuais da população. Enquanto Nedel apresentou, entre 2001 e 2003 um total de 283 Projetos de Lei / Resolução, Pedidos de Informação e Indicações, realizou 2645 Pedidos de Providências no mesmo período. No ano 2001, onde apresentou 590 PPs, esse número representou mais de 50\% de todos os pedidos de providência da Câmara.

${ }^{17}$ Idem 5.
} 
Vicentinos ${ }^{18}$, uma associação da Igreja Católica fundamentalmente "voltada à assistência aos menos favorecidos". Cabe ressaltar a própria representação que Nedel expõe em relação à atividade de vereança, uma construção as voltas da imagem da assistência: "Eu tenho mais de 1.300.000 patrōes, porque ser vereador é servir". Aqui, portanto, na esfera que seria a mais característica do campo político em sua atuação, o vereador apresenta uma permanente interface com sua condição religiosa: seja pelos valores que formam seu caráter e direcionam suas escolhas e posturas; seja pela representação/apresentação direta que faz dos interesses de grupos ligados ao catolicismo; ou ainda pela articulação que mantém com a própria hierarquia da Igreja Católica.

Estas disposições se revelam em sua participação no Grupo de Vereadores Católicos. Nedel teria sido um dos primeiros vereadores a ser procurado pelos representantes da hierarquia para a fundação de tal grupo, do qual apresenta-se hoje como um dos coordenadores. Parece entender este grupo como um espaço através do qual a igreja possa rearticular os representantes do povo identificados com sua doutrina.

Observamos, portanto, que tanto a entrada de Nedel na política como sua permanência e sua atuação cotidiana dentro dela têm relaçôes diretas com a condição religiosa. Inclusive na relação íntima que o vereador apresenta com a hierarquia da Igreja Católica e seus valores, muitas vezes apresentando-se como "a voz da igreja no Parlamento Municipal". Dentro deste bojo somam-se as origens partidárias e empresariais do vereador, construindo em seu entorno uma imagem de caráter conservador, tanto em sua atuação no campo político como no religioso e, indissociavelmente, na interface entre ambos.

\footnotetext{
${ }^{18}$ Sociedade São Vicente de Paulo, criada em 1859 em Lisboa. A SSVP é uma organização católica formada por leigos que desenvolvem atividades de visita domiciliária, acompanham pessoas em situação de doença, marginalidade, carências econômicas, etc. (fonte: www.jornaldamadeira.pt)
} 


\section{CONCLUSÃO}

Podemos dizer que, de certa forma, os quatro vereadores têm a religião como porta-de-entrada na política, posto que, através do envolvimento com a Igreja Católica, foram lançadas as bases para as atuações no campo político. Entretanto, podemos afirmar que, a partir desse ponto de entrada comum, cada trajetória política foi traçada por uma forma diferenciada de entrar na política através do catolicismo. É como se no interior da Igreja Católica existisse uma multiplicidade de "portas-de-en trada" para o campo político. Assim, enquanto Nedel entra na política após compreender seus compromissos de cristão em uma palestra sobre a doutrina social cristã na Associação de Dirigentes Cristãos de Empresa, Besson o faz com base nos trabalhos comunitários que desenvolvia junto ao Secretariado de Ação Social da Arquidiocese de Porto Alegre; enquanto Beto Moesch emerge político no bojo familiar fundado na interface entre política e religião, Maria Celeste adentra a política pelos movimentos de base da igreja, sob forte influência da Teologia da Libertação.

Essas particularidades expressas nas trajetórias religiosas têm relação estreita com as formas ideológicas nas quais os políticos religiosos irão moldar suas atuações no campo da política, seja na adesão partidária, nas "bandeiras" e "lutas", na própria relação com a religião católica, etc.

Como nos mostra Besson, a importância da família cristã é algo presente nas trajetórias dos quatro vereadores, embora seja delineada em matizes diferentes conforme as lógicas por eles acionadas. $\mathrm{Na}$ narrativa de Besson, a família cristã é calcada na idéia de suporte para o "representante" em sua desgastante tarefa de legislar. Diferentemente, Maria Celeste aprofunda no valor da maternidade, na importância do acompanhamento próximo da mãe na criação dos filhos. Beto Moesch destaca a família como uma raiz da qual ele emerge enquanto político e fiel católico; a família é narrada por ele como representação da sua origem e de seus valores. Em Nedel, a família revela-se de forma múltipla, algumas delas aproximando-se das expressas por seus colegas; mas destacamos aqui dentro da dinâmica da diferenciação do aparentemente homogêneo -, 
uma outra forma da família emergir em seu discurso: como argumento eleitoral. Por ocasião das eleiçôes, Nedel, ao trazer em seu marketing eleitoral a expressão "a família, o emprego e o desenvolvimento", destacava a família - enquan to valor cristão - juntamen te com outras idéias baseadas na doutrina social cristã, de forma a divulgar os princípios pelos quais trabalharia na Câmara, para, assim, capitaliza r votos.

Os "princípios cristãos", ao serem in corporados na atividade política, tendem também a adquirir formas múltiplasem seus desdobramentos. Maria Celeste busca na vida de Cristo o embasamento para realizar a "luta pelas minorias", já Nedel aproxima-se, nas palavras de um informante, de um "guardião da moral", um forte defensor dos posicionamentos oficiais da Igreja Católica em torno de temas polêmicos. Para Ervino Besson, a vivência como católico confere ao político uma maior "disciplina", uma "dureza" que direciona as açôes conforme uma política "sem aquela ganância”, sendo para ele, portanto, os princípios cristãos o que embasam o político de forma a direcioná-lo diferenciadamen te do "jogo político" - visto como forma nefasta, fundado na ganância e no oportunismo.

É interessante observar como os princípios cristãos em Beto Moesch estão inextricavelmente ligados à sua proposta ambientalista. Uma boa imagem dessa relação foi expressa por seu assessor de campanha na explicação do simbolismo em torno do logotipo de Beto Moesch: uma figura humana cuja forma representa uma árvore, as pernas são como raízes e sobre os ombros e cabeça ergue-se uma copa com o dizer "Política pela Vida". Segundo o assessor, foi mediante a aliança entre compromissos públicos e sua matriz cristã familiar (raiz), que Beto Moesch buscou constituir a defesa da preservação da vida e do meio ambiente no cenário político. Quanto a isso, Beto afirma: "quem defende o meio ambiente está evangelizando", pois "evangelizar no século XXI é pegar temas atuais e colocar neles as bases cristãs”. Outro pon to interessante a ser destacado é em torno da questão da doutrina social cristã, em muito relevante nas trajetórias de Beto Moesch e João Nedel, e que aponta para um elemento comum entre os quatro vereadores: a religião como base ética no exercício político.

Seja através de um corpo teórico elaborado como a doutrina social 
cristã, presente nas narrativas de Nedel e Moesch, seja na inspiração nos Evangelhos como em Maria Celeste, ou, para Besson, valores incorporados pela vivência junto à comunidade católica que lhe dão uma orientação política "sem ganância", são todas formas diferenciad as do religioso se atualizar como base ética nas narrativas dos vereadores.Como caracteriza Miranda (1999, p. 73), há no discurso contemporâneo de lideranças políticas a representação da ética em duas formas: "contraposta a uma certa forma hegemônica - de conceber o político" ou apresentada simplesmente como " "fundamento' da ação". Ambas estão presentes nas narrativas dos vereadores estudados. O que Miranda caracteriza como a atual "onda ética" está, segundo ela, fortemente ligada a movimentos liderados pela Igreja Católica, que conformam no campo religioso um "apelo ético" baseado na suposição de queética "possui significado único e conhecido de todos" (Miranda, 1999, p. 73).

Assim, a noção de uma ética advinda da formação religiosa atualizase nas narrativas dos vereadores, de forma expressa ou não, em muito ligadas à compreensão de um fundamento último para a ação no campo político, diferenciando-os dos "sem-ética", instituindo um protesto "contra aquilo que tende a reduzir a prática política a uma relação de forças, ao deslocamento da valoração do resultado para a ação ela mesma." (Miranda, 1999, p. 77).

Ao trazermos esses elementos para reflexão, vemos como no interior do Grupo de Vereadores Católicos se articula uma pluralidade de percepções e posicionam entos ideológicos, que, no entanto, convergem em alguns pontos. Como vimos na descrição dos vereadores, o mesmo ponto que, segundo Maria Celeste, dá unidade à diversidade presente no Grupo, em Beto Moesch aparece como o diferencial entre o "político cristão" e o "político não-cristão": a fé. Portanto, na narrativa dos vereadores, o que dá unidade ao Grupo, é justamente o que os diferencia dentro do campo político.

A lógica acessada pelos clérigos ligados à fundação e coordenação do Grupo indica uma tendência no interior da hierarquia da Igreja Católica. Uma lógica que não dicotomiza religião e política de forma a criar uma 
disposição de exclusão entre uma e outra; e, sim, fomentando através de iniciativas ${ }^{19}$ como o Grupo de Vereadores Católicos as possíveis articulaçōes que as dimensões religiosa e política podem assumir; uma tornandose, assim, embasamento para a outra. Essa é, certamente, uma compreensão de relação entre política e religião diferenciada daquela expressa na narrativa de Ervino Besson, quando conta que, ao tornar-se vereador pela primeira vez, é estranhado por parte da comunidade católica com a qual estava ligado. Esse outro olhar direcionado a Besson denota uma tendência no interior do catolicismo que enxerga a política partidária de forma a distanciála do campo religioso; nas palavras do padre Roberto Paz, referindo-se a essa tendência: "A gente vê que nas igrejas, ou nas comunidades eclesiais, ainda há um certo... de não identificar com um partido".

Não há, portanto, um modo unívoco do catolicismo relacionar-se com a política. E para trabalhar essas percepçóes, trazemos a perspectiva que Pierre Sanchis desenvolve sobre a identidade católica, que "por ser 'católica', cabem nelas muitas coisas que o senso comum julgaria in compatíveis" (1986, p. 5). Mas, ao menos no contexto no qual realizamos a pesquisa, podemos afirmar que vem tomando forma e força através das ações de membros da hierarquia da Igreja Católica essa tendência voltada para a "evangelização dos ambientes". Uma ten dência fortemente marcada pela preocupação com a "ampliação do conceito" de político cristão, ou seja, voltada mais para o ajuntamento da diversidade em um mesmo grupo com referência no catolicismo do que a definição de parâmetros identitários definidores do "político cristão". Sanchis aponta como particularidade da Igreja Católica justamente essa sua capacidade de "compatibilizar o incompatível", tornando "mui to difícil a procura, para defini-la, de uma 'forma', mais ainda de uma 'essência".

Assim, na esteira do que Sanchis interpreta ser a "particularidade" católica no campo religioso, observamos em nossa pesquisa como essa

\footnotetext{
${ }^{19}$ Podemos incluir também o Grupo de Parlamentares Católicos e as cartilhas eleitorais lançadas por dom Dadeus Grings.
} 
lógica particular pode ser articulada também no campo político; delineando a tendência da "evangel ização dos ambientes" incorporada na composição do Grupo de Vereadores Católicos, de forma mais a justapor a pluralidade ideológica presente no campo político da Câmara dos Vereadores de Porto Alegre, do que construir uma imagem inflexível em torno do "político cris tão".

Como pudemos observar nas descrições de quatro dos vereadores participantes do Grupo de Vereadores Católicos, cada qual inspira diferentes possibilidades de articulação entre religião e política. Isso nos põe diante dos processos contemporâneosa que JoanildoBuriti refere estarem sob "uma lógica de deslocamento de fronteiras" (2000, p. 1). A pluralidade de possibilidades em deslocar as fronteiras entre religião e política é fundamentada na própria lógica de composição do Grupo, ao passo que, segundo Roberto Paz, "parece que devemos aprender a conviver nesse pluralismo legítimo. Nunca se reprime nenhum tipo de manifestação". Assim, vemos formas de relacionarreligião e política como a de Nedel,mais próximo de um "guardião da moral"; Maria Celeste, buscan do na pesquisa, mas também nos Evangelhos, o embasamento de suas posições; ou de Beto Moesch em seu "modo de evangelizar modernamente". Todos realizam deslocamentos diferenciados entre as fronteiras em contato, sintonizando-se, enquanto participantes do Grupo de Vereadores Católicos, com uma certa "particularidade" católica em congregar a diversidade. Desse modo, como para Sanchis (1986) em sua análise da identidade católica, no contexto de interface entre catolicismo e política também se torna dificultosa a busca de uma "essência" ou uma "forma" católica que permeie as atuações dos vereadores iden tificados com essa confissão. Nesse trabalho, procuramos tecer justamente algumas linhas de reflexão em torno das aproximações possíveis nesse contexto complexo e plural. 


\section{REFERÊNCIAS}

BURITI, Joanildo. Religião e Política na fronteira: desinstitucionalização e deslocamento numa relação historicamente polêmica. In: VII Congresso Latino-americano de Religiāo e etnicidade, 2000, Pádua, Itália.

MIRANDA,Julia. Carisma, sociedadee politica: novas linguagensdo religioso e do político. Rio de Janeiro: Relume Dumará, 1999.

ORO, Ari. Políticos e Religião no Rio Grande do Sul - Brasil. Horizontes Antropológicos. Porto Alegre, ano 7, n. 15, p. 161-179, julho de 2001.

ORO, Ari. Religião e Política nas eleições 2000 em Porto Alegre (RS). Debates do NER. Porto Alegre, ano 2, n. 3, p. 9-70, setembro de 2001.

SANCHIS, Pierre. Uma "identidade católica”? Comunicaçôes do ISER. Rio de Janeiro, ano 5, n. 22, p. 5-16, 1986. 